\title{
Spanish spatial deictic adverbs: Interpretation and discourse functioning with depersonalizing constructions
}

\author{
Els adverbis díctics espacials de l'espanyol: interpretació \\ i funcionament discursiu amb construccions despersonalitzadores
}

\author{
Barbara De Cock
}

Université Catholique de Louvain. barbara.decock@uclouvain.be

Received: 7/04/2018. Accepted: 18/09/2018

\begin{abstract}
In this paper, I analyze the ways in which spatial deictic adverbs function in Spanish. More concretely, through an analysis of spatial deictic adverbs used with depersonalizing constructions, I show how, in the absence of person deictic forms, the interpretation of spatial deictic adverbs depends not only on the physical, but more crucially on contextual cues in the discursive context. Moreover, I show that spatial adverbs used with depersonalizing constructions fulfill different functions in discourse construction than when they are used in combination with person deixis or with a concrete $3^{\text {rd }}$ person reference. Indeed, in the absence of person deixis, spatial deictic adverbs take up crucial functions for the cohesion of the linguistic production.
\end{abstract}

Keywords: adverb; depersonalization; impersonal; Spanish.

Resum: En el present article, analitzem les diferents funcions dels adverbis díctics espacials de l'espanyol. Més concretament, l'anàlisi dels adverbis díctics espacials en construccions despersonalitzadores mostra que, si es produeix una absència de formes díctiques personals, la interpretació dels adverbis díctics espacials no només depèn dels factors físics, sinó també dels factors contextuals del discurs. En aquest sentit, s'observa que els adverbis díctics espacials en construccions despersonalitzadores compleixen funcions diferents que si s'utilitzen junt amb díctics de persona o amb referències concretes de tercera persona. De fet, en absència de la dixi personal, els adverbis díctics espacials compleixen funcions cohesives essencials per a la producció lingüística.

Paraules clau: adverbi; despersonalització; impersonal; espanyol.

\D De Cock, Barbara. 2018. "Spanish spatial deictic adverbs: interpretation and discourse functioning with depersonalizing constructions". Quaderns de Filologia: Estudis Lingüistics XXIII: 59-79. doi: 10.7203/qf.23.13520 



\section{Introduction}

The use of spatial deictics with depersonalizing constructions is the starting point for an analysis that focuses both on the way we interpret spatial deictics, and on the specific position they hold in the construction of discourse.

In this study, I analyze more concretely how spatial deictics are interpreted in the absence of person deixis, viz. when they are the sole deictic form. I argue that, in addition to the relation with and distance to the speaker, also contextual cues play a role, as well as the interaction with other spatial deictic adverbs. In the absence of person deixis, spatial deictic adverbs moreover come to fulfill a crucial role in the creation of discourse cohesion.

I first present the Spanish spatial deictic adverb paradigm (1.1). I then define the depersonalizing constructions, as well as explain why they create a particularly interesting environment for the analysis of spatial deictic adverbs (1.2). Finally, I present the data on which this study is based (1.3).

\subsection{The spatial deictic paradigm}

Spanish has two important series of spatial deictic adverbs expressing location, namely a ternary series on $-i$ and a binary series on $-\dot{a}^{1}$. The variety of spatial deictic forms in Spanish is subject to various factors. On the one hand, the ternary opposition aqui ('here'), ahi ('there'), alli ('over there') is considered locative, and is traditionally associated to the ternary opposition of demonstrative pronouns (est* 'this', es* 'that', aquel* 'that over there') (Eguren, 1999: 958). From a typological perspective, and within the classical opposition between person-oriented and (absolute) distance-oriented systems (Fillmore, 1982: 49-50; Anderson and Keenan, 1985: 285-286; Levinson, 2003: 26-28; Levinson, 2004: 116-117), the Spanish ternary opposition has been described as distance-oriented (Diessel, 1999: 39) but is regularly also considered to be related to the distinction between proximity to the speaker, proximity

\footnotetext{
* I wish to thank Daniel Michaud Maturana for comments on an earlier version of this paper. All remaining errors are, of course, solely my responsibility.

${ }^{1}$ A series of older forms on -ende, such as aquende, allende, is rarely used these days and totally absent from the corpus discussed in this study.
} 
to the hearer and negative proximity (Eguren, 1999: 942; NGLE, 2009: 1313). Moreover, the importance of the subjective dimension of positioning for the choice of a demonstrative has been amply demonstrated (see among others Delbecque 2013, Maldonado 2013). It is therefore not surprising that accounts combining distance and relation to the interaction situation and participants have been proposed (e.g. Hottenroth 1982: 134), among others in terms of position in a conversational dyad (Jungbluth, 2002: 7), and as a double-anchor type system (Da Milano, 2004: 84).

On the other hand, the binary opposition between acá 'here' and allá 'there' represents a proximal-distal distinction, namely in terms of speaker-proximity versus non-speaker-proximity ${ }^{2}$. In contrast with the series on $-i$, the series on $-a$ is often associated with the expression of movement or vague location, possibly in larger spaces, though this distinction is by no means valid throughout all contemporary varieties of Spanish (see Maldonado, 2013). Gómez Sánchez and Jungbluth (2015: 248) describe this series as "[foregrounding] the extension of spaces", which explains its combining with motion verbs. In addition to this semantic difference, regional variation plays a role as well, both with respect to the frequency of the different adverbs and with respect to their semantics (see among other Sedano, 2000, Di Tullio, 2013, Gómez Sánchez and Jungbluth, 2015: 248). For instance, acá is more easily used as a locative in certain Latin-American varieties of Spanish. Even idiolectal variation may be observed (Eguren, 1999: 958; NGLE, 2009: 314). The variation between the five forms from the two series of spatial deictic adverbs is then a complex multifactorial phenomenon, yet the focus of this paper is not on this variation as such, but on how the interpretation of these spatial deictic adverbs is established.

Along with Hanks (1992: 49), I consider (spatial) deixis to be shaped in a dynamic fashion. As Rubba (1996: 228) points out, "the meaning of deictics are highly schematic. That is, they are only partially specified, and therefore may apply across a large number of actual discourse situations". An analysis of the concrete interpretation of these schematic meanings is the object of section 2. Diessel, mentioning Levinson

\footnotetext{
${ }^{2}$ While it was originally a ternary opposition acá, allá, acullá, the latter form is in strong decline (it did not appear in our corpus) and the series is usually considered to be binary from a synchronic perspective (NGLE, 2009: 1313-1314).
} 
(2004), claims that spatial deictics moreover not only indicate location but also "establish (or manipulate) the interlocutors" shared focus of attention" (Diessel 2006: 466). This is relevant for the construction and development of the discourse, as will be shown in section 3 .

\subsection{Depersonalization in Spanish}

Before looking into the specific functioning of spatial deictic adverbs with depersonalizing strategies, I define depersonalization, describe the constructions involved and show the particular interest of studying spatial deictic adverbs used with depersonalizing strategies.

I adopt an onomasiological approach to depersonalization, that is, I include constructions where the agent or experiencer is defocused (either entirely absent, either expressed in a rather vague way). Concretely, this involves constructions with an expressed human subject which remains vague (such as uno 'one', generic 2nd person singular (1), non-specific 3rd person plural (2)), as well as constructions where no human subject is expressed at all (infinitives (3), gerunds, the (medio) passive se-construction (4) and existential haber and presentatives).

(1) Es que asi haces el negocio, te... te compras Is that so make-2SG the trade you-DAT you-DAT buy-2SG alli un montón y te vuelves aquíy las vendes there a lot and REFL turn-2SG here and them sell-2SG por mil pesetas más caras

for thousand pesetas more expensive 'That's the way you do trade, you... you buy a lot over there and you come back here and you sell them for thousand pesetas more.'

(2)

$\begin{array}{llll}- \text { Es } & \text { una planta } & \text { se... } \\ \text { Is } & \text { a plant } & \text { and } & \text { REFL } \\ -¿ Y & \text { la plantaban } & \text { alli } & \text { en los huertos? } \\ \text { And } & \text { it planted-3PL } & \text { there } & \text { in the orchards }\end{array}$

'It's a plant and ... / And they planted it there in the orchards?

$\begin{array}{lllll}\begin{array}{l}\text { De oveja alli } \\ \text { Of sheep there }\end{array} & \text { no } & \text { se } & \text { hacía, } & \text { no. Pero de cabra sí } \\ \text { hacíamos queso } & & & & \\ \text { made-1PL cheese } & & & & \\ \text { did, } & & \text { no. But of goat yes }\end{array}$

'Of sheep it wasn't made over there, no. But we did make goat cheese.' 
(4)

$\begin{array}{llll}\text { Buscar } & \text { por } & \text { todos } & \text { los sitios... } \\ \text { Search-INF } & \text { by } & \text { all } & \text { the places... } \\ \text { 'Search } & \end{array}$

I prefer the term 'depersonalization' to 'impersonal' since many of the constructions involved actually do imply the involvement of a person as agent or experiencer or even a subject that is necessarily human (e.g. indefinite pronoun uno 'one') (see De Cock, ms., for a more elaborate terminological discussion).

This paper focuses on the use of spatial deictic adverbs with depersonalizing constructions for two main reasons. On the one hand, the use of person deixis co-determines the choice for a specific spatial deictic adverb (Hottenroth, 1982: 144). By focusing on depersonalizing constructions which lack a person deictic form, we can analyze the way in which spatial deictic adverbs function autonomously. On the other hand, whereas the specific role of spatial deictic adverbs with depersonalizing constructions has received little attention in research on deixis, research on depersonalizing constructions, by contrast, has pointed at the importance of space descriptions (whether deictic or not) for the interpretation and functioning of some depersonalizing constructions.

In the first place, we know that adjuncts (space description) play a role in creating a generic reading ${ }^{3}$ in depersonalizing constructions (Hernanz, 1990; Casielles, 1994; de Miguel Aparicio, 1992, from a generativist point of view; Rasson, 2016, 2017, for a corpus-based analysis). However, the importance of spatial deictic adverbs in this respect also depends on the type of depersonalizing construction. Thus, the presence of a spatial deictic adverb is one of the factors that significantly correlates with the use of Spanish depersonalizing se, as opposed to uno 'one' (see Rasson, 2017, for a multivariate analysis of uno; De Cock, ms., for a corpus-based multivariate analysis of se vs. uno).

In the second place, there is ample discussion among linguists as to whether a complement of space with existential haber (hay 'there is') is obligatory or optional (see Meulleman and Roegiest, 2012, for an overview and discussion, and Gast and Haas, 2011, for a comparative study of formulaic presentationals in Germanic and Romance). While this research then highlights the importance of space description for

\footnotetext{
${ }^{3}$ In addition to other factors, such as verb aspect.
} 
the functioning and interpretation of depersonalizing constructions, it mainly focusses on the syntactic features of one specific type of construction and it does not distinguish between deictic and non-deictic space descriptions. As shown in this short overview, the importance of space description for depersonalizing constructions has been attested. Yet, the analysis of how spatial deictic adverbs function with respect to depersonalizing constructions remains mainly undeveloped and is the object of this study.

\subsection{The data}

The data for this research are all taken from the informal conversation section of the CORLEC (Corpus del Español Centro-peninsular). Table 1 shows the frequency of spatial deictic adverbs with depersonalizing constructions as compared to the total amount of occurrences of spatial deictic adverbs. The use and frequency of deictics is of course highly genre-dependent (see Gelabert 2006 on spatio-temporal deixis and De Cock 2014 on person deixis). By consequence, the results of this study only hold for informal conversation and caution should be exercised when transposing them to other genres.

\begin{tabular}{|c|c|c|}
\hline & $\begin{array}{c}\text { Total amount of } \\
\text { spatial deictic adverbs }\end{array}$ & $\begin{array}{c}\text { Amount of spatial deictic adverbs used } \\
\text { with depersonalizing constructions }\end{array}$ \\
\hline Aquí & 498 & $58(11.64 \%)$ \\
\hline Ahí & 367 & $29(7.9 \%)$ \\
\hline Allí & 337 & $51(15.1 \%)$ \\
\hline Allá & 45 & $6(13.3 \%)$ \\
\hline Acá & 18 & $4(22.2 \%)$ \\
\hline
\end{tabular}

Table 1. Frequency of spatial deictic adverbs

The comparatively low frequency of acá and allá in this corpus may be related both to their semantics and to their geographic variation. Indeed, it is to be expected that the forms on $-\dot{a}$, which are particularly frequently used in Latin-America, have a lower frequency in this Peninsular Spanish Corpus. The fact that geographic delimitation is certainly 
not the only factor to explain the variation between the series on $-i$ and $-a$, however, is confirmed by the presence of all forms concerned in Peninsular Spanish production. Moreover, forms on $-\dot{i}$ and $-\dot{a}$ may be used within one intervention, as in example (5). In this concrete case, allá is used to signal direction (in combination with the preposition para) and alli location.

$\begin{array}{lll}\text {-Mira, } & \text { allí } & \text { hay sitio. } \\ \text { Look } & \text { there } & \text { there-is place } \\ \text {-Allí } & \text { hay } & \text { sitio. Vaya, vaya para allá. }\end{array}$

There there-is place. Go go over there.

'Look, there is a place. / There is place over there. Go, go over there.'

The corpus data confirm, then, that the series on $-i$ is the preferred one in Peninsular Spanish, yet also show that both series occur in the same geographical circumscription and even within the same utterance. Moreover, the more specific semantics of the series on $-a$ in Peninsular Spanish (tendency to express direction and vague location) may contribute to their low frequency.

\section{How to interpret spatial deictic adverbs?}

\subsection{General principles for the interpretation of (spatial) deixis}

As pointed out in section 1.1, deictics have a schematic meaning. The choice for a specific spatial deictic adverb is then not only determined by physical distance as such but also by the speaker's conceptualization of the distance and his/her taking into account recipient design (Schegloff, 1972; Enfield et al., 2007: 10). Indeed, the speaker aims to establish shared recognitionals, which are valid for both speaker and hearer, since deictics are ultimately a joint construction in interaction (Hanks, 2005). However, as Heritage (2007: 261) points out: "Absolute security of reference is incompatible with progressivity." Indeed, a very precise space description is often not available and/or necessary for the conversational progression. The balance between progressivity and felicitousness of the recognitional seems to be achieved rather adequately. Our data contain only one example (6) where the use of a spatial deictic adverb as a shared recognitional seems somehow problematic. The lack of recognizability becomes clear through the use of a follow-up ques- 
tion ¿En dónde? ('Where?') and the subsequent non-deictic description En Tres Cantos ('In Tres Cantos'), which resolves the misunderstanding. In all other cases, the spatial deictic adverb seems to suffice as shared recognitional.

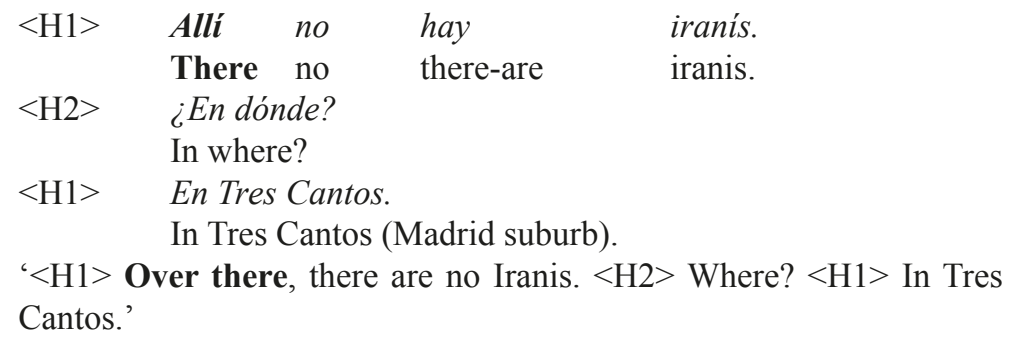

Even a vague space description, however, may be established in varied ways and often relies partially on contextual cues which help to establish the reference of the spatial deictic adverb. Indeed, Sedano (2000: 930) distinguishes for Spanish between deictic, anaphoric and anadeictic (a combination of anaphoric and deictic) functioning in her analysis based on a questionnaire.

\subsection{Person deixis vs. depersonalizing constructions}

As evidenced in the previous section, the relation to the speaker and hearer may play an important part in the interpretation of deixis in various languages. It is then not surprising that the presence of person deictic forms plays a role for the interpretation of spatial deictic adverbs. In the presence of an explicit speaker reference (7), the spatial deictic adverb is interpreted also in connection to the person deixis. Indeed, we interpret aqui as the position of the inclusive 1st person plural (speaker and hearer). When co-appearing with a hearer reference, as in (8), the aqui 'here' reference is once again interpreted as related to the shared interaction situation of the speaker and hearer, and the shared knowledge concerning the difficulty of finding a flat in a certain city. Both examples show that the co-appearance with a hearer-reference (be it expressed by means of a second person or by means of an inclusive first person) causes the deictic to be interpreted as related to the situation of both participants (and not only the speaker's deictic center). 
Podemos hablar aquí todos. can-1PL speak here all. 'We can all speak here.'

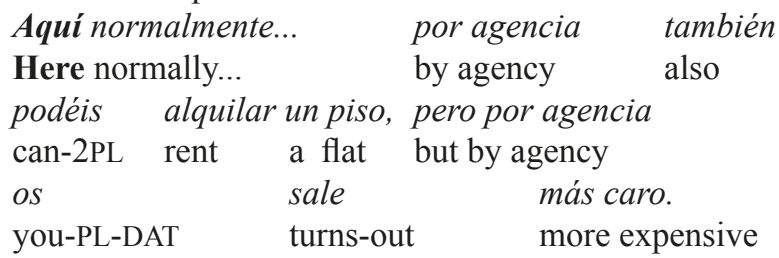

'Here normally you can also rent a flat through an agency, but through an agency will cost you more.'

If construed with person deictic forms, these play a crucial role then in the interpretation of the spatial deictic adverb. We will now turn to the use of spatial deictic adverbs with depersonalizing constructions.

\subsection{Spatial deictic adverbs with depersonalizing constructions}

I now discuss which contextual elements contribute to the interpretation of spatial deictic adverbs with impersonal constructions in my corpus. These may of course also appear when person deixis is present, but in the absence of other deictic forms, they become the first means to establish the reference.

In the first place, spatial deictics may rely on a pointing gesture. This use is closest to the etymological origin of 'deixis', which is derived from the verb deiknunai 'to point'. Yet, not all deictic forms are accompanied by a pointing gesture. Our data unfortunately do not contain visual material, making a detailed analysis of pointing impossible. However, the context may allow for deducing the use of a pointing gesture or, in any case, bodily orientation. In this perspective, aqui 'here' seems to be mostly used in a strictly deictic sense or, at least, without extra contextual cues in the linguistic production, as illustrated below for other spatial deictic adverbs. This is not surprising since the speaker refers to a space typically related to him-/herself, in a situation where (part of) the origo and the speech situation coincide. The egocentricity of language (see Kecskes-Mey, 2008) urges us to interpret utterances as speaker-referring 'by default' and to anchor them to the speaker him-/ herself. All other spatial deictic adverbs, however, do not allow easily for a purely deictic reading, yet rely on contextual cues. 
In the second place, spatial deictic adverbs may be immediately followed by a more specific space description, such as directional arriba 'up' (9) or non-deictic information (10) en el pueblo 'in the village'. Auer et al. (2013: 6) point out that "non-deictic spatial expressions often occur in combination with deictic elements in interaction and that deictic and non-deictic expressions are often mutually paraphrased." Yet, the relationship between both space descriptions (whether both deictic or deictic and non-deictic) is complex. On the one hand, the additional description allows for narrowing down the interpretation of the spatial deictic adverb. On the other hand, the use of a spatial deictic adverb also represents an added value in that it creates a reference point in the interaction, which situates the locations not only in an absolute way but also with respect to the speaker and hearer, and, as such, to the interaction situation.

$\begin{array}{llll}\text {-De las laderas de... de allá arriba, ¿no tienen } & \text { vino? } \\ \text { Of the slopes of... } & \text { of there up not have-3PL } & \text { wine }\end{array}$ -De ahi de los huertos. Si hombre.

Of there of the orchards. Yes man.

'Of the slopes of... of up there, haven't they got wine? / Of there of the orchards. Yes, man.'

Allí en el pueblo pasa igual.
There in the village happens same
'There in the village the same thing happens.'

Thirdly, the reference can be established anaphorically or cataphorically, relying on text cohesion and progression. The link between special distance and text-deictic processes has also been shown for Catalan and English (Ribera, 2007; Cuenca, 2010). In view of this property, Lyons (1977: 676) prefers to describe spatial deictic adverbs as 'pro-locatives', though he also points out that they are simultaneously deictic (since the selection of the adverb is co-determined by the position of the speaker) and anaphoric. Interestingly, such anaphoric or cataphoric uses hardly occur with aqui, which, as pointed out before, is the only form that favours a strictly deictic functioning. Exceptions exist, of course, such as the second occurrence of aqui in (11), which has to be interpreted as referring to previously mentioned Segovia. 

(11)
Que yo se lo dije a mi padre
That I him-DAT it said to my father
porque aqui en Segovia () no los venden.
because here in Segovia (...) not them sell-3PL
Es que aquíno los venden.
Is that here not them sell-3PL
'That I told my dad because here in Segovia (...) they don't sell them. It's that they don't sell them here.'

For other spatial deictic adverbs, the adverb acquires its interpretation then not only from the (physical) position with respect to the speaker or hearer, but mainly from anaphorically or cataphorically available contextual information, as in (12), where alli is interpreted as en Italia. The choice for one spatial deictic adverb over another may be linked rather to the subjective positioning of a place with respect to the conversation dyad and to other deictically expressed places (cf. supra).

En Italia hice el doctora $\langle(d)>$ o allí en jurisprudencia.
In Italy did-1SG the $\mathrm{PhD}$
Allí sí lo pasé

There yes it spent-1SG well

'In Italy I did a PhD there in jurisprudence. There I did have a good time.’

The anaphoric or cataphoric uses represent more than half of the uses with all other spatial deictic adverbs. These uses are regularly cases of what Sedano (2000) calls anadeictic, as in (11), where the deictic functioning of aqui is combined with the anaphora with Segovia.

The link between the spatial deictic adverb and the discursive context is then very different according to the specific adverb. Interestingly, Spanish neuter demonstratives also specialize in very different ways for the expression of links with the discursive context (cf. De Cock, 2013).

In addition to anaphorically and cataphorically established references, the data also contain various clusters of spatial deictic adverbs occurring in each other's vicinity, that is, in the same utterance, or in an immediately preceding or following utterance. Such clusters are particularly challenging, since the context in which we interpret spatial deixis is in those cases mainly (or sometimes exclusively) made up of other spatial deictic adverbs. Clusters spreading over two turns can be 
analyzed in terms of dialogic syntax (Du Bois, 2014). Indeed, by repeating the spatial deictic adverb, the next speaker establishes a shared recognitional and echoes the preceding speaker's choice, as in (13), where the interlocutor echoes not only the spatial deictic adverb but the utterance as a whole.

$\begin{array}{llll}\text { - Mira, } & \text { allí } & \text { hay sitio. } \\ \text { Look-IMP-SG, } & \text { there } & \text { there-is } & \text { place. } \\ \text { - } \text { Allí hay } & \text { sitio. } & & \end{array}$

There there-is place

'Look, there's a place over there. / Over there is a place.'

Clusters within an utterance typically consist of different spatial deictic adverbs contrasting with each other. The contrast may be clarified in context, e.g. Spain vs. Morocco (14). Morocco (Marruecos) is referred to by means of the noun and by means of the spatial deictic adverb alli' 'there'. Because alli is linked to a country (Morocco), we interpret aqui as referring to another country, namely the country in which the interaction is taking place (Spain).

Compras un coche allí que te
buy-2SG a car there that you-DAT
vale la mitad que aquí $y$ te vas (...) a
cost the half than here and you-REFL go-2SG to

Marruecos (...) todos los fines de se[mana]

Morocco (...) all the ends of week

'You buy a car there that costs half of here and you go to Morocco every weekend.'

Frequently, various spatial deictics are combined in order to represent different spaces. They are then interpreted in relation to other spatial deictics, conceptualizing different degrees of distance (15), as is the case for the three forms aquí, allí, allá which establish three different spaces. While alli is interpreted as an anaphora for En Estados Unidos and $a q u i$ as the interaction context (viz. Spain), no concrete reference can be established for allá, merely that it refers to yet another place.

Mira yo, mi experiencia en Estados Unidos ha sido... vamos look I my experience in States United has been... let's go 
no me permite discriminar, es decir, que alli hay not me-DAT allows discriminate, is say, that there there-is más que aquí ni aquí menos que allá, ¿no? more than here nor here less than there, not?

'Look, I, my experience in the United States has been... Let's say, it doesn't allow me to distinguish, say, that there, there is more than over here, nor that there is less over here than over there, right?'

In conclusion, the interpretation of spatial deictic adverbs is not related to deixis only. Contextual cues play a very important role as well, as does the interaction between different spatial deictic adverbs. The importance of each of these factors is highly dependent on the adverb itself. Whereas aqui seems to function without further cues in the linguistic context, probably relying on the classical deictic mechanism of pointing or bodily orientation, the interpretation of other adverbs relies heavily on anaphorically and cataphorically available information. In the absence of person deictic forms, then, many uses of spatial deictic adverbs with depersonalizing constructions are not strictly deictic, yet rely on contextual cues.

\section{Spatial deixis in the construction of discourse}

As I have shown in the preceding section, the interpretation of spatial deictic adverbs often relies on elements in the preceding or following discourse. In this section, I focus on the other side of the medal, namely the importance of spatial deictic adverbs for the development of the interaction as a whole, through its establishing a focus of joint attention (Diessel, 2006: 466). I therefore analyze its position in the utterance and the implications for the informational status of the different elements of the utterance, both in contrast with utterances with a person reference (whether deictically expressed or not), and in contrast with different depersonalizing structures.

Indeed, whereas, in the presence of a person reference form, the spatial deictic adverb usually follows the VP (at least in the informal conversation corpus used for this study), the utterance-initial position of the spatial deictic adverb is more frequent with depersonalizing structures (the proportion varies depending on the concrete spatial deictic adverb but ranges from 1/3 to 1/2). Interestingly, Eguren (1999: 963) claims that, in general, the most natural position of the spatial deictic adverb 
is utterance-initial. In the corpus used for this study, however, the utterance-initial position of the spatial deictic adverb is the preferred one only when used with depersonalizing constructions, not when used with a concrete person reference.

In addition to these quantitative differences, these preposed spatial deictic adverbs also fulfill different functions with respect to the context, echoing Hanks' (1992) call for a more fine-grained description of the functional components of deixis. The adverbs under discussion mainly fulfill presentative, directive and referential functions. Moreover, the presentative one is clearly associated to utterance-initial position, whereas the other functions are much more mobile.

Occurrences of preposed aquí are mainly interpreted as ostensive deixis with a referential function, related to a pointing gesture or at least bodily orientation. That is, they establish the link between the physical interaction situation and the utterance, and place it in a prominent position, as in (16).
(16)
Papá ven.
Que aquí hay mucha diversión.
Daddy come-IMP-SG That here there-is lot diversion
'Daddy, come. Because there's a lot of diversion here.'

With the other spatial deictics adverbs, ostensive deixis is present as well, but, as we have seen, a higher amount of readings is defined anaphorically in the preceding utterances (section 2). Thus, the preposed spatial deictic adverb not only creates a setting for the following VP (and has often an even larger scope) ${ }^{4}$ but is also a locus of discursive cohesion. This is especially the case for the presentative uses, where the following information is, by definition, new. The spatial deictic adverb, relying on the contextual cues presented in section 2 or on its deictic functioning (in case of aqui 'here'), then represents given information. As such, it establishes the link with the preceding discourse and functions in a way similar to topic continuity, which is traditionally associated with NPs or NP-like forms (Givón, 1983). In utterances with a

\footnotetext{
${ }^{4}$ Bestgen (2009) discusses from a psycholinguistic point of view the impact of the sentence-initial position of space adverbials on the comprehension of written texts, highlighting the wider scope and salience of sentence-initial adverbials, as well as their capacity to segment the text in as far as they create a new setting.
} 
person deictic form or another type of specific person reference, it is typically the person that establishes topic continuity.

The postposition of the spatial deictic adverb with depersonalizing constructions, by contrast, is mainly linked to specific syntactic situations, such as the expression of direction (in combination with a preposition), as in (17), or its appearance in a subordinated construction.

Cuando estábamos en Zarauz nosotros teníamos el

When were-1PL in Zarauz we HAD-1PL the...

el batallón en los altos de Orio y habia

the battalion in the heights of Orio and there-were

otros batallones por allí.

other batallions over there.

'When we were in Zarauz, we had the battalion on the heights of Orio and there were other batallions over there.'

As pointed out at the start of this section, with person reference, spatial deictic adverbs are only rarely found in preverbal position. A closer look at the rare cases where the adverb does precede the VP, shows that these utterances are of a specific nature. The series aqui, ahi, alli are mainly used with presentative utterances, which may consist of various strategies, such as cleft-constructions or constructions with verbs such as tener, venir (18).

The preverbal, often utterance-initial position of the spatial deictic adverb is then also motivated by information-structural reasons, namely the desire to present other elements of the utterance as new, in utterance-final position. Thus, from an informational perspective, these utterances with a preverbal spatial deictic adverb and a specific person reference, function in very similar ways as the presentative depersonalizing constructions: the spatial deictic adverb introduces a construction which presents new information, while it establishes the thematic progression. The preverbal, and even utterance-initial, position of the spatial deictic adverb with both person deictic forms and depersonalizing constructions, is then motivated by the information structure. 


\section{Conclusion}

In this study, I have shown that the analysis of the interpretation and discourse functions of spatial deictic adverbs with depersonalizing constructions, sheds light on some important features of spatial deictic adverbs. In the absence of person deixis, the interpretation of spatial deictic adverbs is established differently. In those cases, we must not only take into account the relation to the speaker/hearer and the distance to the speaker, but also other contextual cues concerning the description of space. Whereas aqui mainly relies on physical presence, contextual cues play an important role with the other spatial deictic adverbs. Moreover, spatial deictic adverbs have a different discursive behavior with depersonalizing constructions than with person deixis or other specific person reference. Through their use in combination with presentatives, and in the absence of a concrete person reference or of topic continuity established through NPs, they are the locus of thematic progression and, as such, fulfill a crucial function in discourse cohesion.

\section{References}

Anderson, Stephen \& Keenan, Edward. 1985. Deixis. In Shopen, Timothy (ed.) Language Typology and Syntactic Description: Grammatical Categories and the Lexicon 3. Cambridge: Cambridge University Press, 259308.

Auer, Peter; Hilpert, Martin; Stukenbrock, Anja \& Szmrecsanyi, Benedikt. 2013. Integrating the perspectives on language and space. In Auer, Peter; Hilpert, Martin; Stukenbrock, Anja \& Szmrecsanyi, Benedikt (ed.) Space in Language and Linguistics: Geographical, Interactional, and Cognitive Perspectives. Berlin: de Gruyter, 1-18.

Bestgen, Yves \& the Psycholinguisic Group of the Spatial Framing Adverbial Project. 2009. The discourse functions of sentence-initial adverbials: studies in comprehension. Invited lecture at Linguistic and Psycholinguistic Approaches to Text Structuring. Paris, 21.09.09-23.09.09. Abstract Books, 7-14.

Butt, John \& Benjamin, Carmen. 1988. A New Reference Grammar of Modern Spanish. London: Arnold.

Casielles, Eugenia. 1994. Aspect and arbitrary interpretation. University of Massachusetts Occasional Papers 17: 49-61.

Cuenca, Maria Josep. 2010. Díctics espacials i gramàtica en narracions orals. Estudis Romànics 32: 101-123.http://dx.doi.org/10.2436/20.2500.01.49 
Da Milano, Federica. 2005. La deissi spaziale nelle lingue d'Europa. Milano: Franco Angeli.

De Cock, Barbara. 2013. Entre distancia, discurso e intersubjetividad: los demostrativos neutros en español. Anuario de Letras. Lingüística y Filología 1(2): 7-36. http://dx.doi.org/10.1016/S0185-1373(13)70253-2

De Cock, Barbara. 2014. Profiling Discourse Participants: Forms and Functions in Spanish Conversation and Debates. Amsterdam \& Philadelphia: John Benjamins.

De Cock, Barbara. Ms. Impersonals in context: a multivariate analysis of Spanish uno and se. In Glynn, Dylan \& Krawczak, Karolina (ed.) Modality and Intersubjectivity. Corpus Studies in Epistemic Structuring. Amsterdam \& Philadelphia: John Benjamins.

Delbecque, Nicole. 2013. Anclaje experiencial y epistémico de los demostrativos no situacionales en español. Anuario de Letras. Lingüística y filología 1(2): 87-170. http://dx.doi.org/10.1016/S0185-1373(13)70255-6

de Miguel Aparicio, Elena. 1992. El aspecto en la sintaxis del español: perfectividad e impersonalidad. Madrid: Ediciones de la Universidad Autónoma de Madrid.

Devís Márquez, Pablo. 2003. La impersonalidad y las denominadas construcciones impersonales en español. Zeitschrift für Romanische Philologie 199(3), 393-442. http://dx.doi.org/10.1515/zrph.2003.119.3.393

Diessel, Holger. 1999. Demonstratives: Form, Function, and Grammaticalization. [Typological Studies in Language 42]. Amsterdam \& Philadelphia: John Benjamins.

Diessel, Holger. 2006. Demonstratives, Joint Attention, and the Emergence of Grammar. Cognitive Linguistics 17(4): 463-89. http://dx.doi. org/10.1515/COG.2006.015

Di Tullio, Angela. 2013. Ahí y por ahi en el español de la Argentina. Anuario de Letras. Lingüistica y filología 1(2): 329-356. http://dx.doi.org/10.1016/ S0185-1373(13)70259-3

Du Bois, John. 2014. Towards a dialogic syntax. Cognitive Linguistics 25(3): 359-410. http://dx.doi.org/10.1515/cog-2014-0024

Eguren, Luis. 1999. Pronombres y adverbios demostrativos. Las relaciones deícticas. In Bosque, Ignacio \& Demonte, Violeta (ed.) Gramática descriptiva de la lengua española (vol. 1). Madrid: Espasa Calpe, 929-974.

Enfield, Nick; Stivers, Tanya \& Levinson, Stephen. 2007. Person reference in interaction. In Enfield, Nick \& Stivers, Tanya (ed.) Person Reference in Interaction. Linguistic, Cultural and Social Perspectives. Cambridge: Cambridge University Press, 1-20.

Fauconnier, Gilles. 1984. Espaces mentaux. Aspects de la construction du sens dans les langues naturelles. Paris: Minuit. 
Fernández Soriano, Olga \& Táboas Baylín, Susana. 1999. Construcciones impersonales no reflejas. In Bosque, Ignacio \& Demonte, Violeta (ed.) Gramática descriptiva de la lengua española (vol. 2). Madrid: Espasa Calpe, 1723-1778.

Fillmore, Charles. 1971. Lectures on Deixis. CSLI Publications.

Fillmore, Charles. 1976. Frame semantics and the nature of language. Annals of the New York Academy of Sciences: Conference on the Origin and Development of Language and Speech 280: 20-32.

Gast, Volker \& Haas, Florian. 2011. On the distribution of subject properties in formulaic presentationals of Germanic and Romance. A diachronic-typological approach. In Malchukov, Andrej \& Siewierska, Anna (ed.) Impersonal Constructions. A cross-Linguistic Perspective. Amsterdam \& Philadelphia: John Benjamins, 127-166.

Gelabert-Desnoyer, Jaume. 2006. La deixis espacio-temporal en el lenguaje parlamentario español contemporáneo. Círculo de Lingüística Aplicada a la Comunicación 26: 17-52.

http://webs.ucm.es/info/circulo/no26/gelabert.pdf (Accessed 4/4/2018)

Givón, Talmy. 1983. Topic Continuity in Discourse. A Quantitative Cross Language Study. Studies in Typology 3. Amsterdam: John Benjamins.

Gómez Sánchez, María Elena \& Jungbluth, Konstanze. 2015. European Spanish. In Jungbluth, Konstanze \& Da Milano, Federica (ed.) Manual of Deixis in Romance Languages. Berlin: Walter de Gruyter, 240-257.

Hanks, William. 1992. The indexical ground of deictic reference. In Duranti, Alessandro \& Goodwin, Charles (ed.) Rethinking Context: Language as an Interactive Phenomenon. Cambridge: Cambridge University Press, 43-77.

Hanks, William. 2005. Explorations in the deictic field. Current Anthropology 46(2): 191-220. http://dx.doi.org/10.1086/427120

Heritage, John. 2007. Intersubjectivity and progressivity in person (and place) reference. In Enfield, Nick \& Stivers, Tanya (ed.) Person Reference in Interaction. Linguistic, Cultural and Social Perspectives. Cambridge: Cambridge University Press, 255-280.

Hernanz, María Lluïsa. 1990. En torno a los sujetos arbitrarios: la 2a. persona del singular. In Demonte, Violeta \& Garza Cuarón, Beatriz (ed.) Estudios de lingüística de España y México. México: Colegio de México, 151-178.

Hottenroth, Priska-Monika. 1982. The system of local deixis in Spanish. In Weissenborn, Jürgen \& Klein, Wolfgang (ed.) Here and There. Cross-Linguistic Studies on Deixis and Demonstration. Amsterdam: Mouton, 133-153. 
Jungbluth, Konstanze. 2003. Deictics in the dyad of conversation: Findings in Spanish and some cross-linguistic outlines. In Lenz, Friedrich (ed.) Deictic Conceptualization of Space, Time and Person. Amsterdam \& Philadelphia: John Benjamins, 13-40.

Levinson, Stephen C. 1983. Pragmatics. Cambridge: Cambridge University Press.

Levinson, Stephen C. 2003. Space in Language and Cognition. Explorations in Cognitive Diversity. Cambridge: Cambridge University Press.

Levinson, Stephen C. 2004. Deixis. In Horn, Laurence \& Ward, Gregory (ed.) Handbook of Pragmatics. Oxford: Blackwell, 97-121.

Lyons, John. 1977. Deixis, space and time. Semantics 2: 636-724.

Maldonado, Ricardo. 2013. Niveles de subjetividad en la deixis. El caso de aquí y acá. Anuario de Letras. Lingüística y filología 1(2): 285-326. http://dx.doi.org/10.1016/S0185-1373(13)70258-1

Martín Zorraquino, María Antonia. 1979. Las construcciones pronominales en español. Madrid: Gredos.

Mendikoetxea, Amaya. 1999. Construcciones con se: medias, pasivas e impersonales. In Bosque, Ignacio \& Demonte, Violeta (ed.) Gramática descriptiva de la lengua española (vol. 2). Madrid: Espasa Calpe, 16311722.

Meulleman, Machteld \& Roegiest, Eugeen. 2012. Los locativos en la valencia de la construcción existencial española: ¿actante o circunstante? Zeitschrift für Romanische Philologie 128(1): 57-70. http://dx.doi. org/10.1515/zrp-2012-0003

NGLE = Real Academia Española \& Asociación de Academias de la Lengua Española. (2010). Nueva Gramática de la Lengua Española (NGLE). Madrid: Espasa Calpe.

Rasson, Marie. 2016. Interpretación y tipología del pronombre indefinido uno a partir de tres géneros discursivos. Círculo de Lingüistica Aplicada a la Comunicación 67: 227-272.

http://webs.ucm.es/info/circulo/no67/rasson.pdf (Accessed 4/4/2018)

Rasson, Marie. 2017. Interpretaciones y funciones del pronombre indefinido uno. Análisis de tres variedades geográficas (Chile, España y México) $y$ de tres géneros discursivos (conversaciones, foro digital y redacciones) (Doctoral Dissertation). Louvain-la-Neuve: Université catholique de Louvain. http:// hdl.handle.net/2078.1/192583 (Accessed 4/4/2018)

Ribera, Josep. 2007. Text deixis in narrative sequences. International Journal of English Studies 7(1): 149-168.

Schegloff, Emmanuel. 1972. Sequencing in conversational openings. In Gumperz, John \& Hymes, Dell (ed.) Directions in Sociolinguistics: the 
Ethnography of Communication. New York: Holt, Rinehart \& Winston, 346-380.

Sedano, Mercedes. 2000. Los adverbios demostrativos en diez ciudades hispanohablantes: resultados de una encuesta. In Carbonero Cano, Pedro; Casado Velarde, Manuel \& Gómez Manzano, Pilar (ed.) Lengua y discurso. Estudios dedicados al profesor Vidal Lamíquiz. Madrid: Arco Libros, 914-934.

Siewierska, Anna. 2008. Introduction: impersonalization from a subject-centred vs. agent-centred perspective. Transactions of the Philological Society 106(2): 115-137.

\section{Corpus}

CORLEC (Corpus del Español Centro-peninsular), directed by Professor Francisco Marcos Marín in the Universidad Autónoma de Madrid with the support of the Agencia Nacional para el Desarrollo de Programas del V Centenario (1990-1993).

http://www.lllf.uam.es/ fmarcos/informes/corpus/corpulee.html (Accessed 04/04/2018) 
